\title{
USE OF SEMI-SELETIVE MEDIA FOR DETECTION OF Sclerotinia sclerotiorum ON BEAN AND SOYBEAN SEEDS*
}

\author{
ÂNGELA P. PERES ${ }^{1}$, LUIZ CARLOS B. NASSER ${ }^{2} \&$ JOSÉ DA CRUZ MACHADO ${ }^{1}$
}

${ }^{1}$ Universidade Estadual de Goiás, Rod. GO 330 Anel viário Km 241, CEP 75780-000, Ipameri, GO, Brazil, fone: (62) 4911556; ${ }^{2}$ EMBRAPA-Centro de Pesquisa Agropecuária dos Cerrados (CPAC), Cx. Postal 08223, CEP 73301-970, Planaltina, DF, Brazil, fax: (61) 389-2953, e-mail: nasser@cpac.embrapa.br; ${ }^{3}$ Departamento de Fitopatologia, Universidade Federal de Lavras, Cx. Postal 37, CEP 37200-000, Lavras, MG. Brazil, fax: (35) 3829-1283, e-mail: machado@ufla.br

(Accepted for publication 31/10/2001)

Corresponding author: Ângela Pimenta Peres

PERES, A.P., NASSER, L.C.B. \& MACHADO, J.C. Use of semi-seletive media for detection of Sclerotinia sclerotiorum on bean and soybean seeds. Fitopatologia Brasileira 27:123-127. 2002.

\begin{abstract}
This work was aimed at evaluating the possibility of using bromophenol blue as an indicator for detecting the presence of Sclerotinia sclerotiorum in the seeds of dry-beans (Phaseolus vulgaris) and soybean (Glycine max), through incubation of the seeds on an agar medium and "blotter" substrates. The seeds were artificially inoculated with four S. sclerotiorum isolates, plated on the agar medium, named Neon, and on modified Neon agar media all incubated at 14 and $20^{\circ} \mathrm{C}$ for seven days in the dark. Half of the seeds inoculated were surface desinfested prior to plating on the medium. The seeds showing change of colour in the medium, from blue to light yellow,

as well as formation of typical mycelium and sclerotia in some cases, were considered to be infected or contaminated by S. sclerotiorum. The two incubation temperatures compared did not show significant $(\mathrm{P}<0.05)$ differences in detection level for most of the isolates tested on the different media. According to results obtained in this study, the Neon agar medium with incubation at 14 or $20^{\circ} \mathrm{C}$ has proved to be a reliable and quick method for the detection of S. sclerotiorum mycelium in naturally infected seeds of bean and soybean.

Additional keywords: seed health tests, fungus, Phaseolus vulgaris, Glycine max.

\section{RESUMO}

\section{Uso de meio semi-seletivo para a detecção de Sclerotinia sclerotiorum em sementes de feijões e de soja}

O objetivo deste trabalho foi avaliar a possibilidade do uso do azul de bromofenol como um indicador para determinar a presença of Sclerotinia sclerotiorum em sementes de feijão (Phaseolus vulgaris) e soja (Glycine max), quando da incubação dessas em meios ágar e papel de filtro. As sementes foram inoculadas artificialmente com quatro isolados de $S$. sclerotiorum, plaqueadas em meio ágar, denominado Neon, e em meio Neon modificado, sendo incubadas sob $14 \mathrm{e} 20^{\circ} \mathrm{C}$ por sete dias no escuro. Metade das sementes inoculadas foi desinfestada superficialmente, previamente ao plaqueamento nos meios em teste. As sementes que apresentaram mudança de coloração

do meio ao seu redor, de azul para amarelo com formação de micélio típico ou que produziram escleródios, em alguns casos, foram consideradas infetadas ou contaminadas por S. sclerotiorum. Para a maioria dos isolados testados, não houve diferenças significativas entre as duas temperaturas de incubação comparadas $(\mathrm{P}<0.05)$ nos diferentes meios. De acordo com os resultados obtidos neste estudo, o emprego do meio Neon em condições de incubação às temperaturas de 14 ou $20^{\circ} \mathrm{C}$, pode ser considerado adequado por proporcionar uma detecção rápida e segura de $S$. sclerotiorum em sementes de feijão e soja naturalmente infetadas ou contaminadas
\end{abstract}

\section{INTRODUCTION}

Among the seed-borne fungi causing white mould on irrigated soybean [Glycine Max (L.) Merril] and winter drybean (Phaseolus vulgaris L.) crops, Sclerotinia sclerotiorum (Lib.) de Bary, is one of the most harmful pathogens, causing great losses. According to Nasser \& Sutton (1993), the most significant declines of bean yield since the 1980's in Brazil have been caused by $S$. sclerotiorum, especially in the

\footnotetext{
* Part of MS Thesis of the first author
}

"cerrados" (Brazilian savana) where irrigated bean acreage has increased. The debris of the soybean crop contaminated mainly by the sclerotia may have served as the source of inoculum for beans.

One of the measures employed to prevent introduction of S. sclerotiorum in areas free of this pathogen is the use of healthy seeds. According to Machado (1994), the tolerance index for this pathogen should be nil in seed certification programs in Brazil. At present, health tests applied to detect S. sclerotiorum on seeds ("Blotter test") are based upon either the presence or absence of sclerotia in a seed sample, without 


\section{A.P. Peres et al.}

taking into account the presence of the mycelium of the pathogen inside or on the surface of the seeds. In addition, the use of blotter test to detected $S$. sclerotiorum on seeds requires a 30-day incubation period (Brasil, 1992), which is regarded as unsuitable for application in Seed Health Laboratories where the number of samples to be analysed is high.

A few studies on the development of semi-selective media for identification of $S$. sclerotiorum have been conducted based on production of oxalic acid by the pathogen. This compound causes a change in the colour of the medium to which the indicator bromophenol blue is incorporated (Steadman et al., 1994; Nasser et al., 1995). For some important seed-borne fungi, the development of more specific or selective health testing methods is a growing issue giving the reliability and time-consuming nature of currently used analysis. The objetive of this work was to develop a specific methodology for detection of S. sclerotiorum on bean and soybean seeds which would be more reliable and faster than conventional methods. The basis for this work was the use of bromophenol blue, as an indicator incorporated to PDA (Nasser et al., 1995).

\section{MATERIAL AND METHODS}

The work was carried out in the Seed Pathology Laboratory of the Department of Plant Pathology of the Universidade Federal de Lavras, M.G. in the period of August to December of 1995.

\section{Seed samples}

Seed samples of bean, cv Carioca, and of soybean, cv Cristalina, used in this study were produced in the states of São Paulo and Goiás, in 1995.

\section{Isolates of $\boldsymbol{S}$. sclerotiorum}

Four isolates of $S$. sclerotiorum were used in this work. Two isolates were obtained from sclerotia accompanying seeds of bean produced in the northern and southern region of the State of Minas Gerais, one isolate proceeded from the north eastern region of the State of São Paulo and an fourth isolate came from the fungi collection of the Seed Pathology Laboratory of the Universidade Federal de Lavras and originated from São Gotardo, Alto Paranaíba region, State of Minas Gerais.

The sclerotia in mixture with seeds were surfacedisinfested with a solution of $1 \%$ sodium hypochloride for 5 min, washed off three times in distilled water and transferred to Petri dishes containing PDA medium. The plates were kept in a chamber with temperature of $20 \pm 2{ }^{\circ} \mathrm{C}$ in the dark, for seven days. Discs of $5 \mathrm{~mm}$ in diameter cut off from the borders of the growing colonies were transferred to the Petri dishes containing PDA and incubated under the same conditions previously reported for a five-to-seven-day period, thus obtaining pure cultures.

\section{Seed inoculation assays}

Pure cultures of $S$. sclerotiorum were transferred to the Petri dishes containing PDA medium and incubated for seven days in a chamber at $20 \pm 2{ }^{\circ} \mathrm{C}$ in the dark. At the seventh day of incubation, seeds were rolled over the developing fungal colonies and kept there for $30 \mathrm{~h}$ in the dark. The control treatment consisted of seeds both rolled and incubated on PDA medium.

\section{Preparation of semi-selective medium and seed plating}

One hundred and sixty soybeans and of bean seeds were inoculated with each isolate of S. sclerotiorum and submitted to incubation tests on substrate containing PDA medium amended with $150 \mathrm{ppm}$ of streptomycin sulphate, $150 \mathrm{ppm}$ of $\mathrm{G}$ penicillin and $150 \mathrm{ppm}$ of bromophenol blue, the medium named NEON. These compounds were added to PDA at temperature of $50{ }^{\circ} \mathrm{C}$. The $\mathrm{pH}$ of the medium was adjusted to 4.7 with $1 \mathrm{M}$ chloric acid and sodium hydroxide.

Half of the seeds were surface disinfested with $1 \%$ sodium hypochloride for five minutes, and washed twice in distilled water.

\section{Detection of $S$. sclerotiorum from inoculated seeds on Neon medium}

Seeds inoculated with $S$. sclerotiorum were transferred to plastic dishes containing $15 \mathrm{ml}$ of Neon medium and then incubated in chambers at $14 \pm 2{ }^{\circ} \mathrm{C}$ and $20 \pm 2{ }^{\circ} \mathrm{C}$, for seven days in the dark. During incubation, the plates showing a colour change were analysed under the stereo microscope to assess the growth of typical mycelium and the presence of $S$. sclerotiorum sclerotia.

Four modifications of the technique were tested employing the principle of the changing colour of the Neon medium. The first modification consisted of plating inoculated seeds on two filter paper sheets dipped into liquid Neon medium. The second modification consisted of plating seeds on three filter paper discs dipped into $0.5 \%$ agar solution containing $500 \mathrm{ppm}$ of bromophenol blue. In the third modification, seeds were plated on two filter paper sheets dipped into $0.5 \%$ agar with $500 \mathrm{ppm}$ of bromophenol blue, and covered with another filter paper sheet also dipped into the same agar-medium. The fourth modification consisted of seeds plated on $2 \%$ agar with $50 \mathrm{ppm}$ of bromophenol blue (15 $\mathrm{ml}$ of medium/dish).

For all modifications, each isolate was analysed singly, with each experimental plot consisting of a plastic plate containing ten seeds. A factorial scheme with two treatments of surface disinfestation $\mathrm{x}$ two incubation temperatures was utilized. The experimental design used was the completely randomised treatments with four replications. The data obtained were submitted to variance analysis after transformation by $\log (\mathrm{x}+10)$.

\section{Behaviour of the microflora associated with soybean and bean seeds on Neon medium}

Fungal isolates: Direct isolations of fungi present in soybean and bean seeds were made from samples submitted to the 
"Blotter test" for seven days.

The fungi were transferred from seeds to PDA medium in Petri dishes $9 \mathrm{~cm}$ in diameter and incubated at $20 \pm 2{ }^{\circ} \mathrm{C}$ under an alternating regime of $12 \mathrm{~h}$ light and $12 \mathrm{~h}$ dark. After the incubation period, mycelium discs $(5 \mathrm{~mm}$ in diameter) cut off from the border of the colonies were transferred to fresh PDA medium in Petri dishes and incubated under the same conditions already reported, for a five-toseven-day period, thus obtaining pure cultures.

\section{Behaviour of the fungi on Neon medium}

Fungal isolates were all incubated for seven days at $20 \pm 2{ }^{\circ} \mathrm{C}$ under alternating regimes of $12 \mathrm{~h}$ (light/dark). Mycelial discs of $5 \mathrm{~mm}$ diameter cut off from the border of the colonies were aseptically transferred to the centre of 9 $\mathrm{mm}$ Petri dishes with $15 \mathrm{ml}$ of Neon medium and incubated for $48 \mathrm{~h}$ at $14 \pm 2{ }^{\circ} \mathrm{C}$ and $20 \pm 2{ }^{\circ} \mathrm{C}$ under continuous darkness. Incubation plates were then evaluated for the colour change of the Neon medium around the fungal mycelium disk. Four replications were done for each isolate tested.

\section{RESULTS AND DISCUSSION}

\section{Detection of $S$. sclerotiorum on Neon medium and its modifications}

Rapid development of the isolates artificially inoculated in bean and soybean seeds occurred on Neon medium and all showed a clear change of colour around some seeds after $24 \mathrm{~h}$ of incubation. According to literature (Sutton \& Deverall, 1983) this occurred as result of the production of oxalic acid by the pathogen present in the seeds. Change in colour on Neon medium could already be seen at an average incubation time of $48 \mathrm{~h}$.

Although variation was observed between treatments in relation to isolates and temperatures (Table 1), it was clear that for disinfested seeds, a temperature of $20{ }^{\circ} \mathrm{C}$ was favourable for $S$. sclerotiorum development from seeds.

Despite the variations observed between artificially infected seeds, Neon substrate can be considered accurate in both temperatures tested, as demonstrated for most inoculated isolates. Higher incidences of $S$. sclerotiorum were observed for some isolates when seeds were incubated at $20 \pm 2{ }^{\circ} \mathrm{C}$; at $14 \pm 2{ }^{\circ} \mathrm{C}$ detection of the pathogen in seeds was lower. However, one of the problems faced in the incubation at $20 \pm$ $2{ }^{\circ} \mathrm{C}$ was the more rapid and vigorous growth of other fungi associated with seeds, which makes a quickly and more accurate identification of $S$. sclerotiorum difficult.

Substrates other than PDA containing bromophenol blue, such as blotter, were also proved to be an alternative mean for detecting S. sclerotiorum in seeds. This may be of great importance considering the costs of routine testing. In this study, immersing filter paper in suspension containing bromophenol blue also produced good results in detecting $S$. sclerotiorum. Although some isolates were able to cause colour change of the medium around seeds, in substrates containing only agar plus indicator (potato and dextrose excluded) there was a decrease in the detection of $S$. sclerotiorum.

\section{Behaviour of the microflora associated with soybean and bean seeds in the Neon medium}

Change in the colour of the Neon medium was also caused by a few other organisms tested in addition to $S$. sclerotiorum. Out of 13 isolates within the genera, Aspergillus, Penicillium, Rhizopus, Phomopsis and Fusarium, and the

TABLE 1 - Percentages of Sclerotinia sclerotiorum in bean (Phaseolus vulgaris) and soybean (Glycine max) seeds inoculated with diferents isolates and determined by the Neon medium, under two incubation temperatures

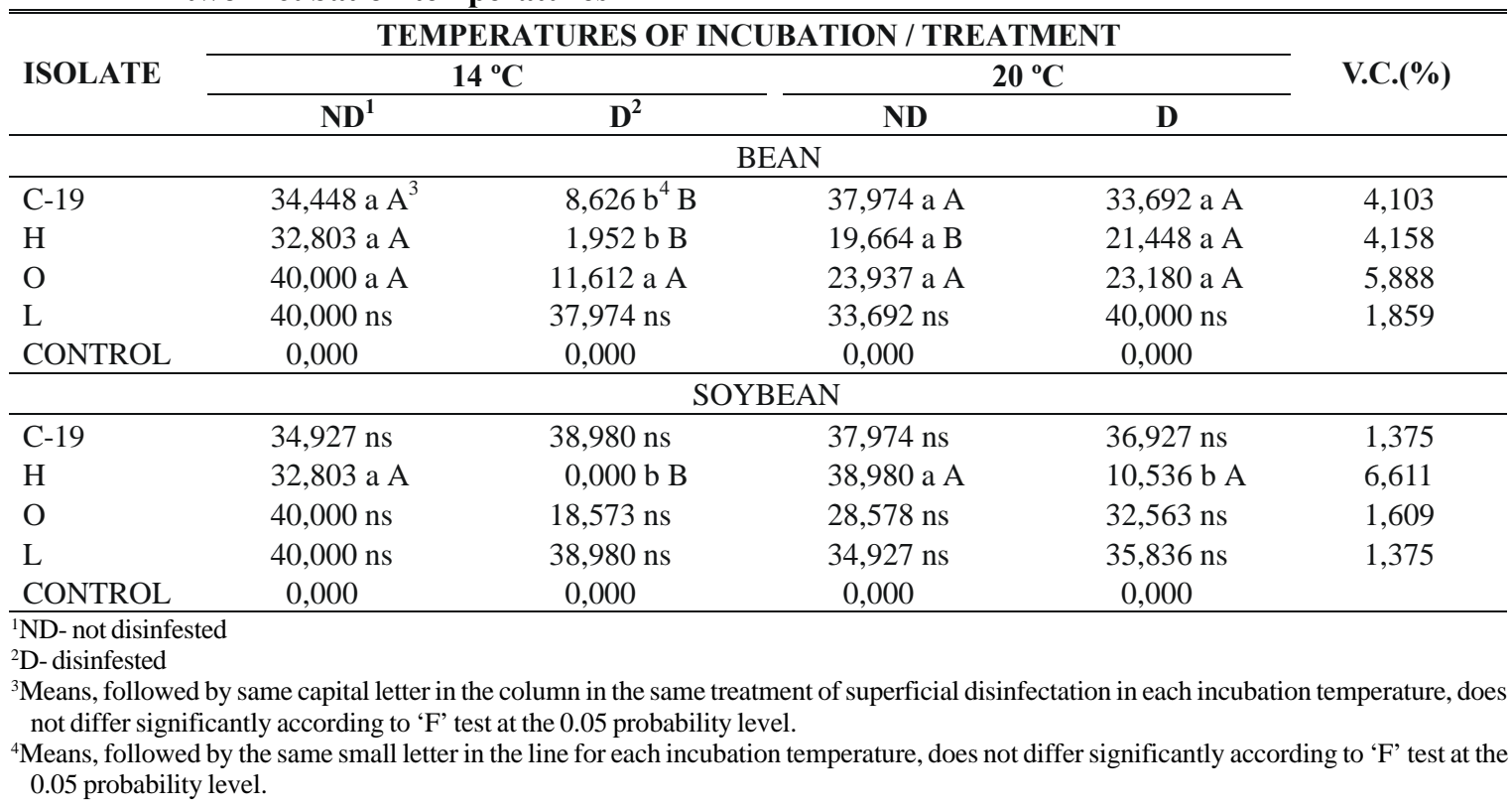


species of Rhizoctonia solani Kühn, Sclerotium rolfsii Sacc., Cladosporium cladosporioides (Fresen.) de Vries, Chaetomium globosum Kunze ex Fr., Macrophomina phaseolina (Tassi) Goid, Alternaria alternata (Fr.) Keissler, Colletotrichum truncatum (Schw.) Andrus \& More, C. lindemuthianum (Sacc \& Magn.) Br \& Cav. and $S$. sclerotiorum (Lib.) de Bary, isolated from seed samples of bean and soybean, two isolates of Aspergillus, eight isolates of Penicillium, two isolates of Rhizopus, one isolate of Fusarium and S. rolfsii Sacc. were also able to change the colour of the Neon medium in variable intensity in comparison with S. sclerotiorum. This development indicates that the Neon medium can be considered as a semi-selective substrate in relation to $S$. sclerotiorum.

To assure the accuracy of this method, observations during seven days of incubation should be recommended for differentiating S. sclerotiorum from other microrganisms, which also can change the colour of the medium. Sclerotium formation in the Neon medium was another evidence of the presence of the fungus, as well as the characteristic mycelial growth pattern around the seeds, where the colour change by S. sclerotiorum takes place.

According to previous reports, colour change of bromophenol blue present in the Neon medium was shown to be an alteration of the $\mathrm{pH}$ of the medium, denoting production of an acidic compound by the pathogens. A similar behaviour was noticed for the isolates of Rhizopus sp, S. rolfsii and $S$. sclerotiorum in the Neon medium. In this case change of colour occurred from blue to a much lighter yellow, which was different from other fungi.

Colour changing by all isolates of $S$. sclerotiorum started after $24 \mathrm{~h}$ of incubation, increasing proportionally to their development. However, some isolates of Penicillium sp. and Aspergillus sp. showed change in the medium colour, but colour was less intense than those of S. sclerotiorum.

Bromophenol blue is an acidic-basic indicator acting within a pH range of 2.8 to 4.6 (Voguel, 1960). The colour change occurring in the Neon medium, from blue to yellow around the seeds, was surely due to the interaction of the indicator with $\mathrm{H}^{+}$ions released into the medium by the oxalic acid production, inducing an isomery process. Thus, $\mathrm{H}^{+}$linked to the indicator formed an isomer of yellowish colour, denoting the presence of the pathogen on seeds.

Previous works have shown that $S$. sclerotiorum grows and produces sclerotia in medium with an initial $\mathrm{pH}$ ranging from 2.5 to 9.0. This allows changes in the $\mathrm{pH}$ of the medium during the growth and production of an organic acid by the pathogen (Le Tourneau, 1979). It is believed that at $\mathrm{pH} 4.7$, the Neon medium becomes even more sensitive since bromophenol blue indicates the presence of the fungus to low acid production.

In comparison with the "Blotter test" in which incubation is of 30 days it turns out that the Neon medium substrate provides conditions to quickly detecting $S$. sclerotiorum in bean and soybean seeds.

Another advantage of the Neon method is that the use of a stereoscopic microscope is only required in cases where colour changes around the seeds confirming the presence of typical mycelium of the fungus. This makes examination quicker and more reliable.

The risk of misidentification of $S$. sclerotiorum is quite low, since the other fungi that change the colour of the agar medium may be easily identified by observing their typical morphological structures. Fungi such as Penicillium oxalicum Currie \& Thom, P. frequentans Westing, $P$. daleae Zaleski, P. purpurogenum Stoll., $P$. chrysogenum Thom., P. citrinum Thom., P. expansum Link ex F. S. Gray, Aspergillus flavus Link ex Fries, A. fumigatus Fresenius, A. niger van Tieghen, A. oryzae (Ahlb.) Cohn, Fusarium oxysporum Schlecht., Rhizopus spp., Endothia parasitica Fr. and Alternaria spp. which also produce acid in culture (Domsch et al., 1980; Agrios, 1988) can be easily distinguished from $S$. sclerotiorum during the seed health analysis.

Detection of S. sclerotiorum by the "Blotter test" is based upon either the presence or absence of sclerotia formed close to seeds. Le Tourneau (1979) states that some isolates of this fungus may lose the ability to produce sclerotia after several transfers. This can be ascribed to the inability of the fungus to synthesize compounds required for sclerotium formation. Deficiency in the production of sclerotia by a few isolates may also be the consequence of some inhibiting substances present in the medium. These facts make the blotter test examination for S. sclerotiorum rather questionable. Extending of the incubation period to 30 days for the blotter test method is a disadvantage; it is too time consuming for routine seed analysis.

Thus, the incorporation of antibiotics in the PDA medium containing bromophenol blue is needed to prevent bacteria activity. Even where colour change in the medium takes place, the differentiation between S. sclerotiorum and bacteria colonies is easily made. For fungal species other than S. sclerotiorum that changing the colour of the Neon substrate, incubation under NUV light (12 h photoperiod), may be reccommended in order to easily identifify these species through their sporulation.

\section{ACKNOWLODGEMENTS}

The authors wish to thank CAPES (Brazilian Agency for Graduate Training), CNPq (Brazilian Council for Scientific and Technological Research) and FAPEMIG (State Research Foundation) for their financial support of this research work.

\section{LITERATURE CITED}

AGRIOS, G.N. Plant Pathology. San Diego. Academic Press. 1988. BRASIL. MINISTÉRIO DA AGRICULTURA E REFORMA AGRÁRIA. Regras para Análise de Sementes. Brasília. MARA. 1992.

DOMSCH, K.H., GAMS, W. \& ANDERSON, TRAUTE-HEIDI Compendium of Soil Fungi. London. Academic Press. 1980.

FERREIRA, L.P. \& SALGADO, C.L. Bactérias. In: Bergamin Filho, 
Use of semi-seletive media for detection of Sclerotinia sclerotiorum...

A., Kimati, H. \& Amorim, L. (Eds.) Manual de Fitopatologia vol. 2. São Paulo. Agronômica Ceres. 1995. pp. 97-131.

LE TOURNEAU, D. Morphology, cytology, and physiology of Sclerotinia species in culture. Phytopathology 69:887-890. 1979.

MACHADO, J.C. Padrões de tolerância de patógenos associados a sementes. Revisão Anual de Patologia de Plantas 2:229-263. 1994.

NASSER, L.C.B., BOLAND, G.J. \& SUTTON, J.C. Meio de cultura semi-seletivo para detecção da viabilidade de escleródios de Sclerotinia sclerotiorum. Fitopatologia Brasileira 28:376. 1995 (Abstracts).

NASSER, L.C.B. \& SUTTON, J.C. Palhada de arroz pode controlar doença do feijoeiro irrigado. Cerrados, pesquisa e tecnologia 1. 1993.

SILVA, S.M. Metodologia de inoculação e comportamento de alguns cultivares de soja em relação a Sclerotinia sclerotiorum. (Tese de mestrado). Lavras. Universidade Federal de Lavras. 1989.

STEADMAN, J.R., MARCINKOWSKA, J. \& RUTLEDGE, S. A semi-seletive medium for isolation of Sclerotinia sclerotiorum. Canadian Journal of Plant Pathology 16:68-70. 1994.

SUTTON, D.C. \& DEVERALL, B.J. Studies on infection of bean (Phaseolus vulgaris) and soybean (Glycine max) by ascospores of Sclerotinia sclerotiorum. Plant Pathology 32:251-261. 1983.

VOGEL, A.I. Química Analítica Quantitativa. Buenos Aires. Editorial Kapelusz. 1960. 